\title{
PODXL Gene
}

National Cancer Institute

\section{Source}

National Cancer Institute. PODXL Gene. NCI Thesaurus. Code C106447.

This gene plays a role in the modulation of cell migration. 